Author version: Mar. Environ. Res., vol.92; 2013; 133-143

\title{
Factors controlling the temporal and spatial variations in Synechococcus abundance in a monsoonal estuary
}

Rajaneesh K. M., Smita Mitbavkar*

CSIR-National Institute of oceanography, Dona Paula, Goa 403 004, India

*Corresponding author. Tel.: + 91832 2450376; fax: + 918322450615.

E-mail address: mitbavkars@nio.org (Smita Mitbavkar)

\begin{abstract}
Temporal and spatial variations in Synechococcus abundance were investigated over an annual cycle (February'10-January'11) along a salinity gradient (0-35) in the tropical Zuari estuary, influenced by south-west monsoons. Synechococcus exhibited salinity preferences with phycoerythrin-rich cells at salinities $>2$ (Synechococcus-PEI), $>20$ (Synechococcus-PEII) and $<1$ (Synechococcus-PEIII) whereas phycocyanin-rich (Synechococcus-PC) dominant at lower salinities. Downstream stratification during monsoon caused Synechococcus group segregation in the surface and nearbottom waters. During monsoon-break and non-monsoon period stabilized waters, increased salinity, temperature, solar radiation and low rainfall favored high Synechococcus abundance whereas unstable waters, increased turbidity and low solar radiation during active monsoon lowered abundance. SYN-PC positively co-related with nitrate and phosphate and SYN-PEI with phosphate. Synechococcus contribution to phytoplankton carbon biomass ranged from 9-29\%. In monsoonal estuaries, rainfall intensity regulates freshwater runoff which modulates the estuarine environment, creating temporal-spatial niche segregation of Synechococcus groups thereby serving as indicator organisms of the estuarine hydrodynamics.
\end{abstract}

Keywords: Estuaries, Monsoon, Picophytoplankton, Salinity, Zuari estuary, Synechococcus 


\section{Introduction}

Picophytoplankton (PP; $<3 \mu \mathrm{m}$ ) have been recognized as significant contributors to the total phytoplankton biomass and primary production in marine (Platt et al., 1983) and freshwater ecosystems (Paerl, 1977). PP comprises two major groups of cyanobacteria, Prochlorococcus and Synechococcus (SYN) and small eukaryotes known as picoeukaryotes. Prochlorococcus is abundant in oligotrophic waters whereas picoeukaryotes are abundant in coastal waters. SYN proliferates in well-lit, eutrophic coastal ecosystems (Jochem, 1988) and are present in comparatively lower numbers in oligotrophic open waters at temperatures ranging from $2^{\circ} \mathrm{C}$ to $30^{\circ} \mathrm{C}$ from tropic, subtropic, temperate and Polar Regions (Partensky et al., 1999). Based on phycobilisome composition, two groups of $S Y N$ have been identified in estuarine ecosystems; one rich in phycoerythrin (PE) and the other in phycocyanin (PC). These studies revealed that PE rich SYN dominates higher saline waters whereas PC rich SYN are abundant in lower saline waters (Murrell and Lores, 2004). Sub-groups of PE rich SYN were also detected in the Mississippi river plume (Liu et al., 2004), Pearl River estuary (Lin et al., 2010) and the Zuari estuary (Mitbavkar et al., 2012) implying the importance of salinity on the distribution of the SYN groups. PP plays an important role in the microbial loop by forming the base of food chain and serving as food for many protists and small invertebrates species (Azam, 1983; Pomeroy, 1974). This carbon transfer through microbial food web creates the important connection between PP and higher trophic levels (Chiang et al., 2013). Studies on PP are well established in the Pacific and Atlantic Oceans whereas comparatively in the Indian Ocean only a few observations have been made (Brown et al., 1999; Campbell et al., 1998). Apart from the open ocean, the importance of PP in coastal regions is now being highlighted (Mitbavkar et al., 2012; Murrell and Lores, 2004).

Estuaries are one of the most productive natural habitats in the world which show wide variation of hydrological characteristics depending on the inputs from upstream rivers. The excess amount of nutrients available in estuarine ecosystems favor the rapid growth of phytoplankton (Madhu et al., 2009; Qiu et al., 2010). Several studies on phytoplankton and PP have been conducted in estuarine region encompassing brackish water to seawater with a wide salinity range (2 to 35). These studies suggest that salinity plays an important role in the spatial distribution of PP groups (Murrell and Lores, 2004; Ray et al., 1989) and also highlights that PP are the major component of the phytoplankton community contributing substantially to the total biomass and primary production in estuarine region of subtropical (Sin et al., 2010) and temperate estuaries (Ning et al., 2000). In tropical estuarine regions studies have mostly focused on larger phytoplankton wherein hydrology and nutrients were indicated as the major dynamic factors influencing the phytoplankton biomass 
and composition (Costa et al., 2009). However, there are few studies on PP especially SYN distribution in tropical and subtropical estuarine and coastal environments (Lin et al., 2010; Qiu et al., 2010).

In the tropics, estuaries influenced by monsoons support very productive fisheries, which in turn are sustained via a healthy food chain supported by a strong foundation, the phytoplankton. There are few studies conducted in monsoonal estuaries. These findings showed that increase in freshwater discharge influences the PP growth (Lin et al., 2010; Qiu et al., 2010). Such areas serve as good model ecosystems for studying the dynamics of PP on temporal and spatial scales. For the first time we have studied the distribution of this organism in a monsoonal estuary where the tides and freshwater runoff regulate the hydrodynamics on an annual scale and also where short spells of breaks in monsoon are experienced during the monsoon season. The aim of the present study was to assess whether the distribution of SYN, the most dominant PP group, is determined by the temporal and spatial variations in environmental factors regulated by the freshwater runoff. We hypothesized that SYN population structure is influenced by both, the temporal and spatial variations in environmental factors, with low abundance during monsoon and dominance of different groups along the salinity gradient. As such SYN groups can serve as indicator organisms in estuarine regions depicting the hydrodynamics across the estuary.

\section{Materials and Methods}

\subsection{Study area}

Sampling was carried out in the Zuari estuary (Goa) located along the central west coast of India (Fig. 1, Table 1). It is one of the major estuaries of Goa and important for agriculture, fisheries and transportation of mines (iron and manganese ore). It originates at Hemad-Barshen in the Western Ghats and flows up to Arabian Sea with a length of $65 \mathrm{~km}$. It's cross sectional area decreases from the mouth to head. This location experiences three seasons: the pre-monsoon (PrM; February to May), the southwest monsoon (MON; June to September) and the post-monsoon (PoM; October to January). During the study period, a total of $3723.5 \mathrm{~mm}$ rainfall was recorded which was relatively higher than that in previous years (Indian Meteorological Department). Out of that, $\sim 92 \%$ of precipitation occurred during the southwest MON. Consequently during MON, the main channel receives huge amounts of riverine freshwater through Kushavathi, Sanguem Rivers and small streams at many points along its length. This creates a river runoff exceeding $400 \mathrm{~m}^{3} \mathrm{~s}^{-1}$ whereas rest of the year freshwater runoff is $<10 \mathrm{~m}^{3} \mathrm{~s}^{-1}$ (Shetye and Murty, 1987). Tides occur in this estuary up to a distance of about $50 \mathrm{~km}$ and the increase in the elevation of the estuarine channel prevents tides 
from propagating beyond this distance (Shetye, 1999). Average depth of this estuary is $\sim 5 \mathrm{~m}$ with the catchment area of $550 \mathrm{~km}^{2}$. Tides are semidiurnal, with the highest height of $2.3 \mathrm{~m}$ during spring tide and $\sim 1$ m during neap tide (Manoj and Unnikrishnan, 2009). Cumbarjua canal, which is at about 11 $\mathrm{km}$ distance from the mouth of the estuary, connects the Zuari estuary to the adjacent Mandovi estuary and is also involved in the regulation of the water flow (Qasim and Sen Gupta, 1981). (Fig. 1 and Table 1 - preferred position)

\subsection{Sampling}

Monthly sampling was carried out in the Zuari estuary from February 2010 to January 2011 (Table 1). Surface and near-bottom water (NBW) samples were collected from 10 stations with a Niskin sampler (Fig. 1). Vertical profiles of temperature and salinity were determined using portable seabird CTD (SBE 19 plus). Water transparency was measured with a secchi disk (SD). Rainfall data for the study period were acquired from the Indian Meteorological Department (IMD) (Table 2). Chlorophyll $a(\mathrm{chl} a)$ was measured following standard methods (Parsons et al., 1984). Nutrients (nitrate $\left(\mathrm{NO}_{3}-\mathrm{N}\right)$, phosphate $\left(\mathrm{PO}_{4}-\mathrm{P}\right)$, nitrite $\left(\mathrm{NO}_{2}-\mathrm{N}\right)$ and silicate $\left(\mathrm{SiO}_{4}\right)$ ) were analyzed by SKALAR SAN ${ }^{\text {lus }}$ ANALYSER. For PP, seawater samples were preserved with paraformaldehyde $\left(0.2 \%\right.$ final concentration), quick frozen in liquid nitrogen and stored at $-80^{\circ} \mathrm{C}$ until analysis. (Table 2preferred position)

\subsection{Flow cytometric analysis of Synechococcus}

Prior to analysis, frozen samples were thawed and then analyzed by a flow cytometer (FACS Aria II) equipped with blue $(488 \mathrm{~nm})$ and red $(630 \mathrm{~nm})$ lasers. Forward angle light scatter (FALS), right angle light scatter (RALS), red fluorescence from chlorophyll $(>650 \mathrm{~nm})$ and phycocyanin $(630 \mathrm{~nm})$ and orange fluorescence from phycoerythrin $(564-606 \mathrm{~nm})$ were recorded from each particle after excitation by lasers. Data obtained was processed with the BD FacsDiva (Version 6.2) software. The different $S Y N$ groups present in the sample could be discriminated according to their specific fluorescence and scattering properties. Yellow green latex beads of $2 \mu \mathrm{m}$ (polysciences co., USA) were added to the sample as internal standards to calibrate cell fluorescence emission and light scatter signals, which allowed comparison of fluorescence and cell size among different samples. Based on flow cytometric signatures, two groups of $S Y N$ were distinguished: one rich in phycoerythrin (SYN-PE) and the other in phycocyanin (SYN-PC) throughout the study period. RALS and FALS (proxy for cell size) signals revealed that the cell size of SYN-PC is bigger than SYN-PE whereas chlorophyll fluorescence is comparable with SYN-PE (Fig. 2). The SYN-PE group was further differentiated into 2 subgroups based on the phycoerythrin fluorescence intensity and was designated as SYN-PEI which had a lower fluorescence intensity and SYN-PEII with a comparatively 
higher fluorescence intensity. Another group of SYN-PE whose flow cytrometric signatures were similar to SYN-PEI but which was found only in freshwater was designated as SYN-PEIII. (Fig. 2 preferred position)

\subsection{Carbon biomass estimation}

Phytoplankton carbon biomass was derived from chl $a$ using a carbon to chlorophyll ratio of 40 (Gallegos, 2001). Choice of this value was based on the fact that the dominant species of diatoms in our study area (Patil and Anil, 2011) were similar to that found in Chesapeake Bay (Marshal et al., 2009).

For calculating the SYN carbon biomass, initially RALS data was converted to cell diameter as explained by Worden et al. (2004). Subsequently, the cell diameter was used to estimate the biovolume using the equation, $\mathrm{V}=\pi / 6\left(\mathrm{~d}^{3}\right)$, assuming $S Y N$ cells to be spherical. Factors for different SYN groups were derived from the biovolume to carbon conversion factor of $254 \mathrm{fg} \mathrm{C \mu m^{-3 }}$ (Baudoux et al., 2007). From these estimates, the percentage contribution of SYN to the total phytoplankton carbon biomass was calculated.

\subsection{Data analysis}

Three-way analysis of variance (ANOVA) was used to assess the significant temporal and spatial variations in cell abundance $(\log (\mathrm{x}+1))$ of the $S Y N$ groups. Principal component analysis (PCA) was performed for the environmental data to identify the key factors which influence the SYN groups. Principal components (PC's) having eigenvalues greater than 1 were considered for further analysis. Stepwise multiple linear regression analyses were performed between factor scores of PC's and cell abundance $(\log (\mathrm{x}+1))$ of different $S Y N$ groups to evaluate the possible factors that affect the SYN abundance. Above statistical analysis was performed using SPSS statistics 16.0 with the significance level of 0.05 . Statistica 8 software was used to find the significance among environmental factors, SYN carbon biomass (\%), phytoplankton carbon biomass and SYN-PC: SYNPE.

\section{Results}

\subsection{Environmental parameters}

During PrM, surface water temperature was $\sim 27^{\circ} \mathrm{C}$ in February and increased gradually to $33^{\circ} \mathrm{C}$ in May. Correspondingly, seawater intrusion towards the upstream also increased during this period (Fig. $3 g$ and h). After onset of MON (June), a drop in surface water temperature $\left(<28^{\circ} \mathrm{C}\right.$ ) and salinity $(<21)$ was observed. During MON the estuary was stratified downstream, with strong stratification in August up to S5 (Fig. $3 \mathrm{i}$ and j). In July, when rainfall was low, rise in temperature $\left(29^{\circ} \mathrm{C}\right)$ and 
salinity (26) was detected at S1. During PoM, temperature was low $\left(<27^{\circ} \mathrm{C}\right)$ (Fig. 3e and f). In October the estuary was stratified as a result of continuing rainfall until November (Table 2). Subsequently (December and January) salinity started increasing as a consequence of cessation in rainfall. There was not much difference in temperature and salinity between surface and NBW during PrM and PoM (except in October). The seasonal trend of chl $a$ concentration (surface and NBW) was PrM $<$ PoM $<$ MON. During PrM, chl $a$ concentration increased along the transect with

highest value upstream $\left(3.03 \mu \mathrm{g}^{-1}\right)$. During MON the trend was reversed with highest value downstream $\left(<12 \mu \mathrm{g} \mathrm{l}^{-1}\right)$. Chl $a$ concentration was higher in surface waters in August as compared to NBW, whereas the reverse was observed in September (Fig. 3o and p). Chl a concentration peaked in January and November with slightly lower concentration in NBW (Fig. 3q and r). During MON, nitrate (22 to $37.71 \mu \mathrm{M}$ ) and phosphate (3 to $7.48 \mu \mathrm{M}$ ) concentrations were high. Nitrate concentration showed a decreasing trend from mouth to head of the estuary with higher values at surface than that in the NBW whereas phosphate showed an opposite trend (Fig. 4c, d, i and j). Nitrate and phosphate peaked in May $(13.32 \mu \mathrm{M})$ and April $(4.78 \mu \mathrm{M})$. During rest of the months, concentrations in surface and NBW were low (Fig. 4a-i). Nitrite concentration was high in April and May at S6 (Fig. 4m and n) and lowest during MON (Fig. 4o and p). Silicate concentrations showed an increasing trend from downstream to upstream of the estuary except during MON season (Fig. 4sx). Silicate concentrations were highest in September (44.54 to $155.29 \mu \mathrm{M}$ ). (Fig. 3 and 4- preferred position)

\subsection{Temporal and spatial variation of Synechococcus}

Cell abundance of all SYN groups showed distinct temporal variations. Three-way ANOVA indicated significant monthly $(p<0.001)$ and spatial $(p<0.01)$ variations in all SYN groups whereas vertical variation was not significant within the stations. SYN-PEI abundance in the surface and NBW was highest in February at the mouth of the estuary $\left(0.97 \times 10^{5}\right.$ cells ml $\left.{ }^{-1}\right)$ and reduced further upstream. Cell abundance reduced from March to May with a peak at S8 (Fig. 5a and b). It declined further by an order of magnitude after onset of MON (June) in surface and NBW and increased in July up to S5 (Fig. 5c and d). Subsequently, abundance decreased in August and increased in September (Fig. 5c and d). At the beginning of the PoM (October), abundance was high up to S5 with higher abundance in the NBW (Fig. 5e and f). From November to January, cell abundance was low $\left(<0.25 \times 10^{5}\right.$ cells $\left.\mathrm{ml}^{-1}\right)$. SYN-PEII showed a decreasing trend from mouth to middle of the estuary where salinity was $>20$. Monthly variation was very similar to SYN-PEI with lower abundance except during PoM (Fig. 5g-1). During PoM, cell abundance at the mouth of the estuary was $\sim 0.5 \times 10^{5}$ cells $\mathrm{ml}^{-1}$ (surface and NBW), which was higher than SYN-PEI abundance. During Mon, NBW cell abundance was higher than that at the surface. SYN-PEIII was observed at the 
upstream end (S9 and S10) during PrM (Fig. 5m and n). After the onset of MON, abundance declined in surface and NBW and it was observed from middle of the estuary where salinity was < 0.5. Low (surface and NBW; $<0.07 \times 10^{5}$ cells $\mathrm{ml}^{-1}$ ) abundance during MON, continued in the PoM season (October) (Fig. 5o and p). From November, abundance started increasing $\left(>0.13 \times 10^{5}\right.$ cells $\mathrm{ml}^{-1}$ ). SYN-PC showed an increasing trend from mouth to head of the estuary in surface and NBW. Abundance was high during PrM with highest abundance recorded in the NBW of S10 $\left(1 \times 10^{5}\right.$ cells $\mathrm{ml}^{-1}$ ) in May. With the onset of MON, cell abundance declined (Fig. 5u and v) and later increased in July $\left(\sim 0.34 \times 10^{5}\right.$ cells ml $\left.{ }^{-1}\right)$ in the middle of the estuary in surface and NBW. In August, it increased $\left(0.39 \times 10^{5}\right.$ cells $\left.\mathrm{ml}^{-1}\right)$ at the estuary mouth (surface) with a decreasing trend upstream whereas in the NBW abundance was low. During PoM, distribution trend was similar to PrM with comparatively lower abundance in surface and NBW (5w and x). (Fig. 5 - preferred position)

\subsection{Influence of environmental factors on Synechococcus}

The total SYN abundance showed a significant positive correlation with temperature. (Fig. 6a). When plotted against salinity, SYN-PE and SYN-PC distribution showed a clear spatial pattern (Fig. 6b) wherein PC cells were abundant in the low saline waters whereas the PE cells were abundant in the high saline waters. The seasonal cycle of salinity also influenced SYN abundance in the Zuari estuary. During PrM, total SYN abundance showed a significant negative correlation $(\mathrm{r}=-0.301, p<$ $0.001)$ with salinity which was reversed during MON $(\mathrm{r}=0.568, p<0.001)$ and $\mathrm{PoM}(\mathrm{r}=0.256, p<$ 0.05). PCA displayed three factors in PrM and MON and four in PoM, which explained 68\%, 64\% and $87 \%$ of the variations of the environmental factors, respectively. During PrM, PC1 was highly loaded with phosphate, silicate and nitrite (Table 3). A strong load of salinity was detected in PC3. Stepwise multiple regression analysis showed that all SYN groups and chl $a$ were significantly correlated with PC1 $(p<0.05)$ and PC3 (except chl $a$; $p<0.01)$, which also included chl $a$ whereas only SYN-PC correlated with PC2 (Table 4). During MON, SYN groups and chl a were strongly associated with PC1 where phosphate and salinity were highly loaded. SYN-PEIII and chl $a$ were negatively related to PC2. PC3 was loaded with light (0.63) and nitrite (-0.74) where SYN-PC was positively correlated. Like PrM, all SYN groups were significantly correlated to salinity which was associated with PC2 along with nitrite during PoM (Table 3 and 4). SYN-PC alone showed positive relation to PC1 where nitrate and phosphate were strongly loaded. None of the SYN groups showed correlation to PC3 which included temperature (0.75) and light (-0.90). Chl $a$ indicated positive correlation to PC4 (Table 4). (Table 3 and 4; Fig. 6 - preferred position) 


\subsection{Contribution of Synechococcus to total phytoplankton carbon biomass}

Phytoplankton carbon biomass along the estuary varied from 50 to $127 \mu \mathrm{g} \mathrm{C} \mathrm{1-1} \mathrm{with} \mathrm{higher}$ carbon biomass (127 $\mu \mathrm{g} \mathrm{C}^{-1}$ ) up to S5 at the surface (Fig. 7a and b). In the NBW, it was lower compared to that at the surface at the mouth of the estuary. SYN carbon contribution (\%) to the total phytoplankton carbon biomass varied from 9 to $29 \%$ (surface and NBW; Fig. 7c and d). SYN contributed more to the total carbon at S8 and downstream end of the estuary. Compared to surface, NBW contribution was higher downstream. SYN-PEI $(\sim 13 \%)$ and SYN-PEII $(\sim 16 \%)$ groups contributed higher downstream. Their contribution was slightly higher in the NBW as compared to that in the surface. SYN-PC contributed higher ( $17 \%$ ) upstream (surface and NBW). SYN-PEIII contributed $(\sim 4 \%)$ only at the upstream (surface and NBW) end of the estuary. Significant negative correlation was observed between phytoplankton carbon biomass and total SYN carbon contribution in the estuary (Fig. 8a). Total SYN carbon contribution showed a significant positive correlation with salinity and phosphate (Fig. 8b and c). (Fig. 7 and 8 - preferred position)

\section{Discussion}

In the Zuari estuary, the annual variations in hydrodynamics were mainly controlled by the river runoff and tides during MON and tidal activity during non-MON periods (Qasim and Sen Gupta, 1981; Shetye and Murty, 1987). As a result, during dry season the estuary is vertically homogenous whereas during wet season it is stratified (Qasim and Sen Gupta, 1981; Shetye and Murty, 1987). Monsoonal influence can be such that the entire estuary is dominated by low saline (salinity 11) waters as was observed in August. Similar observations have been reported from the Mandovi estuary (salinity 0), which is adjacent to the Zuari estuary (Vijith et al., 2009). However, active and break phases in rainfall also brings weekly variations in water chemistry (Qasim and Sen Gupta, 1981).

\subsection{Spatial variations of SYN distribution.}

Variations in salinity throughout the estuary were reflected in the distribution of SYN groups. Transition in dominance from PC-rich to PE-rich SYN at salinities of $\sim 20-25$ found in this study is consistent with the studies carried out in subtropical estuaries such as Pensacola Bay (Murrell and Lores, 2004), lower Chesapeake Bay (Ray et al., 1989) and Pearl river estuary (Zhang et al., 2013). This illustrates that salinity plays a key role in the spatial distribution of $S Y N$ along this monsoon influenced tropical estuary. To support this, in the present study PC's which strongly associated with salinity showed a significant correlation to all the SYN groups. 
Vertical variation of SYN abundance was not significant in the present study as was observed for the Pearl River (Lin et al., 2010) where depth was comparitvely higher $(<60 \mathrm{~m})$ than the Zuari estaury (Table 1). However, during MON at the estuary mouth high abundance of SYN-PEII in the NBW and SYN-PC in surface compared to that at surface and NBW respectively indicates that increased river runoff resulting in stratification of the water column influenced the distribution of these groups. Similarly, the higher abundance of SYN-PEI in NBW and SYN-PC in surface waters during early PoM (October) also shows the influence of rainfall and the resultant freshwater run off. Presence of SYN-PC throughout the estuary even during dry season when there is no possibility of its influx from fresh water suggests that these groups are halotolerant and they can survive at high salinities. However, their comparatively lower abundance downstream implies that their growth rates are affected at higher salinities. Waterbury et al. (1986) reported that SYN-PE cells have an obligate requirement for elevated concentrations of ions while marine SYN isolates that lack PE are halotolerant and grows equally well in the seawater or freshwater. The presence of SYN-PE up to the upstream end could be facilitated by the tidal entry of seawater. SYN-PEI and SYN-PEII observed at higher salinities were also previously reported from North western Arabian coast, Mississippi river plume and the Pearl River estuary (Lin et al., 2010; Liu et al., 1998; Liu et al., 2004). The high PE intensity SYN strain is considered as characteristic of oceanic waters (SYN-PEII) and other strain (SYN-PEI) represents the coastal waters (Campbell et al., 1998). This suggests a possibility of the SYN-PEII influx from offshore waters into the estuary. Increased SYN PEIII abundance in fresh water suggests that this could be a freshwater adapted strain. Different SYN strains have been reported in a variety of freshwater systems based on their pigment characteristics (Callieri, 1996).

\subsection{Temporal variation of SYN groups}

Total SYN abundance range in the present study was comparable to previous report for the same estuary (Mitbavkar et al., 2012) and higher than that reported for the other tropical coastal waters (Agawin et al., 2003). However, it was 1 to 2 magnitudes lower than that reported for subtropical estuaries like Florida Bay (Phlips et al., 1999), Chesapeake Bay (Wang et al., 2011) and Pensacola Bay (Marshall and Nesius, 1996; Murrell and Lores, 2004). While in Chesapeake Bay SYN cell abundance often exceeds $10^{6}$ cells ml $\mathrm{ml}^{-1}$, in a temperate estuary it ranged from $10^{2}$ to $10^{5} \mathrm{cells} \mathrm{ml}^{-1}$ (Agawin et al., 1998; Ning et al., 2000). The seasonal cycle of the SYN population differed from that in subtropical and temperate coastal and estuarine regions which can be attributed to the influence of South West monsoon that creates a seasonal cycle of hydrodynamics that varies from other latitudinal regions. 
Several studies have established temperature as the key factor influencing the seasonal dynamics of SYN in tropics to temperate estuaries such as Chesapeake Bay (Ray et al., 1989; Wang et al., 2011), Pearl River (Qiu et al., 2010), Pensacola Bay (Murrell and Lores, 2004), Francisco Bay (Ning et al., 2000), Blanes Bay (Agawin et al., 1998), Western Pacific coast (Tsai et al., 2008) and Sagami Bay (Mitbavkar et al., 2009). These studies showed that warm period is favorable for SYN spp. Similarly, in the present study the total SYN abundance showed significant positive correlation with temperature (Fig. 6a), although a narrow temperature range exists ( 24 to $32^{\circ} \mathrm{C}$ ) throughout the year as compared to that in the subtropical $\left(10-30^{\circ} \mathrm{C}\right)$ and temperate estuaries $\left(10-24^{\circ} \mathrm{C}\right)$. The optimum temperature range of 27 to $30^{\circ} \mathrm{C}$ was found to be favorable for SYN in the present study. Variations in the spatial distribution of salinity during the three seasons were reflected in the temporal distribution of SYN-PC which showed a negative relation with salinity as expected during the PrM and PoM but during MON it showed a positive relation because of the comparatively lower salinity downstream resulting in its higher abundance. SYN-PEI and SYN-PEII showed a positive and SYNPEIII negative relation with salinity during the three seasons indicating that SYN-PEI and SYN-PEII preferred higher salinity and SYN-PEIII lower salinity.

Recent studies elucidate negative correlation between SYN abundance and nutrients (Qiu et al., 2010; Zhang et al., 2013). These studies suggest that SYN prefers reduced form of nitrate (ammonia) which was not measured in the present study. In this study, the positive correlation of SYN-PC to PC's which strongly associated with nitrate and phosphate during the non-MON periods and with phosphate during the MON season suggests that both these nutrients could be important for this group. A laboratory experimental study proved that PC rich SYN grows well in high nitrate and phosphate concentration whereas PE rich SYN cannot tolerate high nitrate concentration (Ernst et al., 2005). Wyman et al. (1985) reported that SYN can use nitrate with lower concentration efficiently and dominates the conditions. These findings corroborate the non-significant relation of SYN-PE subgroups with nitrate and the positive relation with phosphate of SYN-PEI and SYN-PEII during the PrM and MON season in this study (Table 4). These observations indicate that nutrients could play a vital role in the temporal variation of SYN groups. Since silicate is not a requirement for this PP, the positive relationship in some cases may not be a causal one.

The low cell abundance observed during active MON could be a consequence of the prevailing environmental conditions such as increased turbidity due to influx of huge quantities of fresh water and restricted light availability due to increased cloud cover (Devassy and Goes, 1988). Biological processes like grazing (Wetz et al., 2011) and viral lysis (Pan et al., 2007) are also known to play a role in controlling SYN abundance, which we did not account for in the present study. During MON 
break increased salinity, temperature, nutrients (nitrate and phosphate), solar radiation and lower rainfall could have facilitated an increase in SYN abundance along with high phytoplankton biomass. Similar variations in phytoplankton biomass have been observed in this estuary with high and low biomass during MON break and during peak of MON, respectively (Patil and Anil, 2011; Pednekar et al., 2011). The increased freshwater runoff during this period was reflected in the dominance of SYN-PC from the mouth to head of the estuary and absence of SYN-PEII as well as lower cell abundance of SYN-PEIII. Towards the end of MON season, with the subsiding rainfall intensity and the corresponding lowered freshwater influx downstream along with the high nutrient concentrations and solar radiation, SYN-PEI, SYN-PEII and SYN-PEIII abundance increased in the estuary. Lowering of SYN-PC abundance could be a result of the gradual increase in salinity and low temperature. This period is considered to be conducive for the proliferation of phytoplankton (Patil and Anil, 2011; Pednekar et al., 2011) wherein phytoplankton biomass showed significant positive correlation with silicate. During PoM, all the SYN groups showed similar distribution as observed in PrM indicating return of favorable environmental conditions for their growth.

\subsection{Contribution of Synechococcus to total phytoplankton carbon biomass}

The contribution of SYN to the total phytoplankton carbon biomass in the Zuari estuary (9 to 29 \%) was lower than that reported for the Chesapeake Bay sub-estuary (34 to $52 \%$; salinity 19.5 to 23.7) dominated by cyanobacteria (Ray et al., 1989) and higher than that reported in a tropical coastal region $(<16 \%$ ) at the river mouth (Agawin et al., 2003). However, contribution of picoplankton biomass to total phytoplankton biomass in the Cochin estuary, along the west coast of India, influenced by the SW monsoon ranged between $6.5 \%$ (salinity 3 to 9 ) and $11.2 \%$ (salinity > 30; Madhu et al., 2009). In the present study SYN carbon contribution was inversely related to total phytoplankton biomass, which suggests that dominance of larger phytoplankton. Similarly a study conducted in North Carolina estuary showed inverse relation between picoplankton contribution $(\sim$ $40 \%$; salinity 0 to 26) and phytoplankton biomass (Gaulke et al., 2010) and concluded that variation in PP carbon contributions depends on various factors such as nutrients, light and stability of water column. These observations suggest that SYN contribution to total phytoplankton carbon biomass was within the range of other tropical estuaries and although lower than that reported for sub-tropical estuaries, could play a vital role in the microbial food web dynamics of estuarine regions.

In monsoonal estuaries where the fresh water runoff and tides regulate the hydrodynamics during the MON and non-MON periods respectively, the distribution pattern of these organisms both spatially (horizontal and vertical) and temporally, can serve as indicators of the source of water as 
well as the water stability (mixed or stratified) at a particular location in the estuary thereby providing information about the physical factors regulating the estuarine dynamics.

\section{Acknowledgements}

The authors wish to thank The Director, National Institute of Oceanography for his support. We are grateful to Dr. Sathish Shetye and Dr. A.C. Anil, Scientist, for their encouragement and support. We thank Mr. D. Sundar for providing CTD data. We also acknowledge anonymous reviewers for their valuable comments. This is NIO contribution \#.

\section{References}

Agawin, N., Duarte, C., Agusti, S., McManus, L., 2003. Abundance, biomass and growth rates of Synechococcus sp. in a tropical coastal ecosystem (Philippines, South China Sea). Estuarine, Coastal and Shelf Science 56, 493-502.

Agawin, N.S., Duarte, C.M., Agusti, S., 1998. Growth and abundance of Synechococcus sp. in a Mediterranean Bay: seasonality and relationship with temperature. Marine Ecology Progress Series 170, 45-53.

Azam, L., 1983. The Ecological Role of water-column microbes in the sea. Marine Ecology Progress Series 10, 257-263.

Baudoux, A.C., Veldhuis, M.J., Witte, H.J., Brussaard, C.P., 2007. Viruses as mortality agents of picophytoplankton in the deep chlorophyll maximum layer during IRONAGES III. Limnology and Oceanography 52, 2519-2529.

Brown, S.L., Landry, M.R., Barber, R.T., Campbell, L., Garrison, D.L., Gowing, M.M., 1999. Picophytoplankton dynamics and production in the Arabian Sea during the 1995 Southwest Monsoon. Deep Sea Research Part II: Topical Studies in Oceanography 46, 1745-1768.

Callieri, C., 1996. Extinction coefficient of red, green and blue light and its influence on picocyanobacterial types in lakes at different trophic levels. Memorie-Istituto Italiano Di Idrobiologia Dott Marco De Marchi 54, 135-142.

Campbell, L., Landry, M., Constantinou, J., Nolla, H., Brown, S., Liu, H., Caron, D., 1998. Response of microbial community structure to environmental forcing in the Arabian Sea. Deep-Sea Research Part II 45, 2301-2325.

Chiang, K.P., Tsai, A.Y., Tsai, P.J., Gong, G.C., Tsai, S.F., 2013. Coupling of the spatial dynamic of picoplankton and nanoflagellate grazing pressure and carbon flow of the microbial food web in the subtropical pelagic continental shelf ecosystem. Biogeosciences Discussions 10, 233-263.

Costa, L., Huszar, V., Ovalle, A., 2009. Phytoplankton functional groups in a tropical estuary: hydrological control and nutrient limitation. Estuaries and Coasts 32, 508-521. 
Devassy, V., Goes, J., 1988. Phytoplankton community structure and succession in a tropical estuarine complex (central west coast of India). Estuarine, Coastal and Shelf Science 27, 671685.

Ernst, A., Deicher, M., Herman, P. M. J., Wollenzien, U.I.A., 2005. Nitrate and Phosphate Affect Cultivability of Cyanobacteria from Environments with Low Nutrient Levels. Applied and environmental microbiology 71, 3379-3383.

Gallegos, C.L., 2001. Calculating optical water quality targets to restore and protect submersed aquatic vegetation: overcoming problems in partitioning the diffuse attenuation coefficient for photosynthetically active radiation. Estuaries 24, 381-397.

Gaulke, A.K., Wetz, M.S., Paerl, H.W., 2010. Picophytoplankton: a major contributor to planktonic biomass and primary production in a eutrophic, river-dominated estuary. Estuarine, coastal and shelf science $90,45-54$.

Jochem, F., 1988. On the distribution and importance of picocyanobacteria in a boreal inshore area (Kiel Bight, Western Baltic). Journal of plankton research 10, 1009-1022.

Lin, D., Zhu, A., Xu, Z., Huang, L., Fang, H., 2010. Dynamics of photosynthetic picoplankton in a subtropical estuary and adjacent shelf waters. Journal of the Marine Biological Association of the United Kingdom 90, 1319-1329.

Liu, H., Campbell, L., Landry, M., Nolla, H., Brown, S., Constantinou, J., 1998. Prochlorococcus and Synechococcus growth rates and contributions to production in the Arabian Sea during the 1995 Southwest and Northeast Monsoons. Deep-Sea Research Part II 45, 2327-2352.

Liu, H., Dagg, M., Campbell, L., Urban-Rich, J., 2004. Picophytoplankton and bacterioplankton in the Mississippi River plume and its adjacent waters. Estuaries and Coasts 27, 147-156.

Madhu, N.V., Jyothibabu, R., Balachandran, K.K., 2009. Monsoon-induced changes in the sizefractionated phytoplankton biomass and production rate in the estuarine and coastal waters of southwest coast of India. Environmental Monitoring Assessment 166, 521-528.

Manoj, N., Unnikrishnan, A., 2009. Tidal circulation and salinity distribution in the Mandovi and Zuari estuaries: case study. Journal of waterway, port, coastal, and ocean engineering 135, 278287.

Marshall, H.G., Lane, M.F., Nesius, K.K., Burchardt, L., 2009. Assessment and significance of phytoplankton species composition within Chesapeake Bay and Virginia tributaries through a long-term monitoring program. Environmental Monitoring Assessment 150, 143-155.

Marshall, H., Nesius, K., 1996. Phytoplankton composition in relation to primary production in Chesapeake Bay. Marine Biology 125, 611-617.

Mitbavkar, S., Rajaneesh, K., Anil, A., Sundar, D., 2012. Picophytoplankton community in a tropical estuary: Detection of Prochlorococcus-like populations. Estuarine, Coastal and Shelf Science 107, 159-164.

Mitbavkar, S., Saino, T., Horimoto, N., Kanda, J., Ishimaru, T., 2009. Role of environment and hydrography in determining the picoplankton community structure of Sagami Bay, Japan. Journal of oceanography 65, 195-208. 
Murrell, M.C., Lores, E.M., 2004. Phytoplankton and zooplankton seasonal dynamics in a subtropical estuary: importance of cyanobacteria. Journal of plankton research 26, 371-382.

Ning, X., Cloern, J.E., Cole, B.E., 2000. Spatial and temporal variability of picocyanobacteria Synechococcus sp. in San Francisco Bay. Limnology and Oceanography, 695-702.

Paerl, H.W., 1977. Ultraphytoplankton biomass and production in some New Zealand lakes. New Zealand journal of marine and freshwater research 11, 297-305.

Pan, L., Zhang, J., Zhang, L., 2007. Picophytoplankton, nanophytoplankton, heterotrohpic bacteria and viruses in the Changjiang Estuary and adjacent coastal waters. Journal of plankton research 29, 187-197.

Partensky, F., Hess, W., Vaulot, D., 1999. Prochlorococcus, a marine photosynthetic prokaryote of global significance. Microbiology and Molecular Biology Reviews 63, 106-127.

Patil, J.S., Anil, A.C., 2011. Variations in phytoplankton community in a monsoon-influenced tropical estuary. Environmental Monitoring Assessment 182, 291-300.

Pednekar, S.M., Matondkar, S.G.P., Gomes, H.D.R., Goes, J.I., Parab, S., Kerkar, V., 2011. Finescale responses of phytoplankton to freshwater influx in a tropical monsoonal estuary following the onset of southwest monsoon. Journal of Earth System Science 120, 545-556.

Phlips, E.J., Badylak, S., Lynch, T.C., 1999. Blooms of the picoplanktonic cyanobacterium Synechococcus in Florida Bay, a subtropical inner-shelf lagoon. Limnology and Oceanography $44,1166-1175$.

Platt, T., Rao, D.S., Irwin, B., 1983. Photosthesis of picoplankton in the oligotrophic ocean. Nature 301, 702-704.

Pomeroy, L.R., 1974. The ocean's food web, a changing paradigm. Bioscience 24, 499-504.

Qasim, S., Sen Gupta, R., 1981. Environmental characteristics of the Mandovi-Zuari estuarine system in Goa. Estuarine, Coastal and Shelf Science 13, 557-578.

Qiu, D., Huang, L., Zhang, J., Lin, S., 2010. Phytoplankton dynamics in and near the highly eutrophic Pearl River Estuary, South China Sea. Continental Shelf Research 30, 177-186.

Ray, R.T., Haas, L.W., Sieracki, M.E., 1989. Autotrophic picoplankton dynamics in a Chesapeake Bay sub-estuary. Marine Ecology Progress Series MESEDT 52, 273-285.

Shetye, S., Murty, C., 1987. Seasonal variation of the salinity in the Zuari estuary, Goa, India. Journal of Earth System Science 96, 249-257.

Shetye, S.R., 1999. Propagation of tides in the Mandovi and Zuari estuaries, Sadhana (Academy Proceedings in Engineering Sciences). Indian Academy of Sciences 24, 5-16.

Sin, Y., Wetzel, R.L., Anderson, I.C., 2000. Seasonal variation of size-fractionated phytoplankton along the salinity gradient in the York River estuary, Virginia (USA). Journal of Plankton Research 22, 1945-1960. 
Tsai, A.Y., Chiang, K.P., Chang, J., Gong, G.C., 2008. Seasonal variations in trophic dynamics of nanoflagellates and picoplankton in coastal waters of the western subtropical Pacific Ocean. Aquatic Microbial Ecology 51, 263-274.

Vijith, V., Sundar, D., Shetye, S., 2009. Time-dependence of salinity in monsoonal estuaries. Estuarine, Coastal and Shelf Science 85, 601-608.

Wang, K., Wommack, K.E., Chen, F., 2011. Abundance and distribution of Synechococcus spp. and cyanophages in the Chesapeake Bay. Applied and Environmental Microbiology 77, 7459-7468.

Waterbury, J.B., Watson, S.W., Valois, F.W., Franks, D.G., 1986. Biological and ecological characterization of the marine unicellular cyanobacterium Synechococcus. Canadian Bulletin of Fisheries and Aquatic Sciences 214, 71-120.

Wetz, M.S., Paerl, H.W., Taylor, J.C., Leonard, J.A., 2011. Environmental controls upon picophytoplankton growth and biomass in a eutrophic estuary. Aquatic Microbial Ecology 63, 133.

Worden, A.Z., Nolan, J.K., Palenik, B., 2004. Assessing the dynamics and ecology of marine picophytoplankton: The importance of the eukaryotic component. Limnology and Oceanography, 168-179.

Wyman, M., Gregory, R., Carr, N., 1985. Novel role for phycoerythrin in a marine cyanobacterium, Synechococcus strain DC2. Science 230, 818-820.

Zhang, X., Shi, Z., Ye, F., Zeng, Y., Huang, X., 2013. Picophytoplankton abundance and distribution in three contrasting periods in the Pearl River Estuary, South China. Marine and Freshwater Research 64, 692-705. 


\section{Figure legends}

Fig. 1. Location of the study area.

Fig. 2. Flow cytometric analysis of (a-c) seawater, (d-f) brackish water, and (g-i) freshwater samples from the Zuari estuary.

Fig. 3. Temporal variations in (a-f) temperature, (g-l) salinity, (m-r) chlorophyll $a$ concentrations and (s-u) secchi disk depth in the Zuari estuary.

Fig. 4. Temporal variations in nutrient concentrations. (a-f) Nitrate, (g-l) phosphate, (m-r) nitrite and (s-x) silicate concentrations.

Fig. 5. Temporal variations in distribution of Synechococcus groups. (a-f) SYN-PEI, (g-1) SYN-PEII, (m-r) SYN-PEIII and (s-x) SYN-PC.

Fig. 6. Relationship between (a) total SYN abundance with temperature and (b) ratio of PC and PE rich SYN with salinity in the Zuari estuary. The curve was fitted under the logarithmic equation model.

Fig. 7. (a, b) Total phytoplankton carbon biomass and (c, d) percentage contribution of Synechococcus to the total phytoplankton carbon biomass in the Zuari estuary.

Fig. 8. Correlation analysis of total SYN carbon contribution (\%) with (a) total phytoplankton carbon biomass, (b) salinity, (c) phosphate. The curve was fitted under the logarithmic equation model. 
Table 1. Details of sampling stations in the Zuari estuary.

\begin{tabular}{clcccc}
\hline $\begin{array}{c}\text { Station } \\
\text { No. }\end{array}$ & Station name & Latitude & Longitude & $\begin{array}{c}\text { Distance from } \\
\text { mouth }(\mathrm{km})\end{array}$ & $\begin{array}{c}\text { Approximate } \\
\text { depth }(\mathrm{m})\end{array}$ \\
\hline 1 & Marmugao & $1^{\circ} 25^{\circ} 16.9^{\prime \prime}$ & $73^{\circ} 47^{\prime} 36.9^{\prime \prime}$ & 0 & 16 \\
2 & Chicalim & $15^{\circ} 25^{\prime} 8.5^{\prime \prime}$ & $73^{\circ} 47^{\prime} 22.4^{\prime \prime}$ & 5.8 & 5 \\
3 & Island & $1^{\circ} 25^{\prime} 57.4^{\prime \prime}$ & $73^{\circ} 47^{\prime} 57.0^{\prime \prime}$ & 8.6 & 5 \\
4 & Sancoale & $1^{\circ} 25^{\prime} 45.1^{\prime \prime}$ & $73^{\circ} 47^{\prime} 30.6^{\prime \prime}$ & 11 & 7.1 \\
5 & Cortalim & $1^{\circ} 25^{\prime} 32.0^{\prime \prime}$ & $73^{\circ} 47^{\prime} 50.2^{\prime \prime}$ & 13 & 9.6 \\
6 & Loutulim & $15^{\circ} 25^{\prime} 54.0^{\prime \prime}$ & $73^{\circ} 47^{\prime} 24.4^{\prime \prime}$ & 19.7 & 10.5 \\
7 & Borim & $15^{\circ} 25^{\prime} 03.6^{\prime \prime}$ & $73^{\circ} 47^{\prime} 58.0^{\prime \prime}$ & 23.9 & 12.9 \\
8 & Shiroda & $1^{\circ} 25^{\prime} 12.3^{\prime \prime}$ & $73^{\circ} 47^{\prime} 55.5^{\prime \prime}$ & 31.4 & 9.1 \\
9 & Kushavati & $15^{\circ} 25^{\prime} 31.7^{\prime \prime}$ & $73^{\circ} 47^{\prime} 28.3^{\prime \prime}$ & 38.4 & 9.9 \\
10 & Sanvordem & $1^{\circ} 25^{\prime} 01.1^{\prime \prime}$ & $73^{\circ} 47^{\prime} 36.0^{\prime \prime}$ & 42.2 & 4.9 \\
\hline
\end{tabular}

Table 2. Rainfall data for the sampling days.

\begin{tabular}{ccc}
\hline Sr No. & $\begin{array}{c}\text { Sampling } \\
\text { dates }\end{array}$ & $\begin{array}{c}\text { Rainfall } \\
(\mathrm{mm})\end{array}$ \\
\hline 1 & 29-Jan-10 & 0 \\
2 & 03-Mar-10 & 0 \\
3 & 01-Apr-10 & 0 \\
4 & 29-Apr-10 & 0 \\
5 & 27-Jun-10 & 57.8 \\
6 & 13-Jul-10 & 0.2 \\
7 & 11-Aug-10 & 51.7 \\
8 & 17-Sep-10 & 69.8 \\
9 & 23-Oct-10 & 55.4 \\
10 & 06-Nov-10 & 3 \\
11 & 06-Dec-10 & 0 \\
12 & 10-Jan-11 & 0 \\
\hline
\end{tabular}


Table 3. Rotated component matrix (RCM) with varifactors (principal components, PCs) extracted in different seasons.

\begin{tabular}{|c|c|c|c|c|c|c|c|c|c|c|}
\hline \multirow{2}{*}{ Parameter } & \multicolumn{3}{|c|}{ Pre-monsoon (PrM) } & \multicolumn{3}{|c|}{ Monsoon (MON) } & \multicolumn{4}{|c|}{ Post-monsoon (PoM) } \\
\hline & $\mathrm{PC} 1$ & $\mathrm{PC} 2$ & PC3 & PC1 & $\mathrm{PC} 2$ & PC3 & $\mathrm{PC} 1$ & $\mathrm{PC} 2$ & PC3 & $\mathrm{PC} 4$ \\
\hline Salinity & -0.02 & -0.08 & 0.94 & 0.70 & 0.02 & -0.10 & -0.24 & 0.76 & 0.04 & -0.49 \\
\hline Temperature & -0.06 & 0.72 & -0.05 & 0.33 & 0.47 & 0.36 & 0.33 & 0.24 & 0.75 & -0.05 \\
\hline Secchi disk depth & -0.13 & -0.51 & 0.15 & -0.45 & 0.13 & 0.63 & -0.02 & 0.15 & -0.90 & -0.02 \\
\hline Nitrate & -0.34 & 0.63 & 0.12 & -0.47 & 0.69 & -0.21 & 0.90 & -0.30 & 0.08 & -0.14 \\
\hline Phosphate & 0.92 & -0.16 & 0.11 & 0.87 & -0.07 & 0.24 & 0.89 & 0.24 & 0.24 & 0.14 \\
\hline Nitrite & 0.60 & 0.56 & 0.32 & -0.20 & 0.09 & -0.74 & 0.08 & 0.89 & 0.00 & 0.14 \\
\hline Silicate & 0.82 & 0.01 & -0.45 & -0.02 & -0.87 & -0.02 & -0.04 & -0.01 & -0.01 & 0.98 \\
\hline Eigenvalues & 2.00 & 1.52 & 1.24 & 1.82 & 1.49 & 1.19 & 1.77 & 1.60 & 1.44 & 1.25 \\
\hline$\%$ of Variance & 28.61 & 21.76 & 17.68 & 26.05 & 21.27 & 16.96 & 25.21 & 22.91 & 20.56 & 17.89 \\
\hline Cumulative $\%$ & 28.61 & 50.38 & 68.06 & 26.05 & 47.32 & 64.28 & 25.21 & 48.12 & 68.67 & 86.57 \\
\hline
\end{tabular}


Table 4. Regression analysis of the factor scores (as independent factors) for the abundance of SYN groups in different seasons.

\begin{tabular}{|c|c|c|c|c|c|c|}
\hline \multirow{2}{*}{$\begin{array}{l}\text { Dependent } \\
\text { factor }\end{array}$} & \multirow[t]{2}{*}{$R^{2}$} & \multirow[t]{2}{*}{$F$} & \multicolumn{4}{|c|}{$\beta$} \\
\hline & & & PC1 & $\mathrm{PC} 2$ & $\mathrm{PC} 3$ & $\mathrm{PC} 4$ \\
\hline \multicolumn{7}{|l|}{ Pre-monsoon } \\
\hline$S Y N-P C$ & 0.40 & $51.21 * *$ & $0.184^{*}$ & $0.250 * *$ & $-0.630 * *$ & - \\
\hline SYN-PEI & 0.55 & $94.27 * *$ & $0.200^{*}$ & 0.004 & $0.740 * *$ & - \\
\hline SYN-PEII & 0.67 & $163.55 * *$ & $-0.197 *$ & -0.148 & $0.823 * *$ & - \\
\hline SYN-PEIII & 0.39 & $50.11 * *$ & $-0.192 *$ & -0.560 & $-0.625^{* *}$ & - \\
\hline Chlorophyll $a$ & 0.16 & $14.56^{* *}$ & 0.060 & 0.139 & $-0.397 * *$ & - \\
\hline \multicolumn{7}{|l|}{ Monsoon } \\
\hline$S Y N-P C$ & 0.41 & $13.81 * *$ & $0.555^{* *}$ & -0.740 & $0.327 * *$ & - \\
\hline SYN-PEI & 0.29 & $30.69 * *$ & $0.534 * *$ & 0.038 & 0.058 & - \\
\hline SYN-PEII & 0.10 & $8.95 * *$ & $0.323 * *$ & $0.206^{*}$ & 0.055 & - \\
\hline SYN-PEIII & 0.16 & $15.47 * *$ & $-0.410 * *$ & $-0.226^{*}$ & 0.032 & - \\
\hline Chlorophyll $a$ & 0.05 & $4.21 *$ & $0.213^{*}$ & $-0.228 *$ & 0.054 & - \\
\hline \multicolumn{7}{|l|}{ Post-monsoon } \\
\hline$S Y N-P C$ & 0.43 & $51.12 * *$ & $0.257^{*}$ & $-0.655^{* *}$ & -0.004 & $0.516^{* *}$ \\
\hline SYN-PEI & 0.51 & $70.58 * *$ & -0.011 & $0.714^{* *}$ & 0.000 & $-0.162 *$ \\
\hline$S Y N-P E I I$ & 0.84 & $84.22 * *$ & -0.079 & $0.736^{* *}$ & 0.001 & $-0.538 * *$ \\
\hline SYN-PEIII & 0.50 & $16.01 * *$ & 0.060 & $-0.691 * *$ & 0.004 & 0.125 \\
\hline Chlorophyll $a$ & 0.30 & $4.16^{*}$ & -0.508 & 0.030 & -1.980 & $0.208 *$ \\
\hline
\end{tabular}




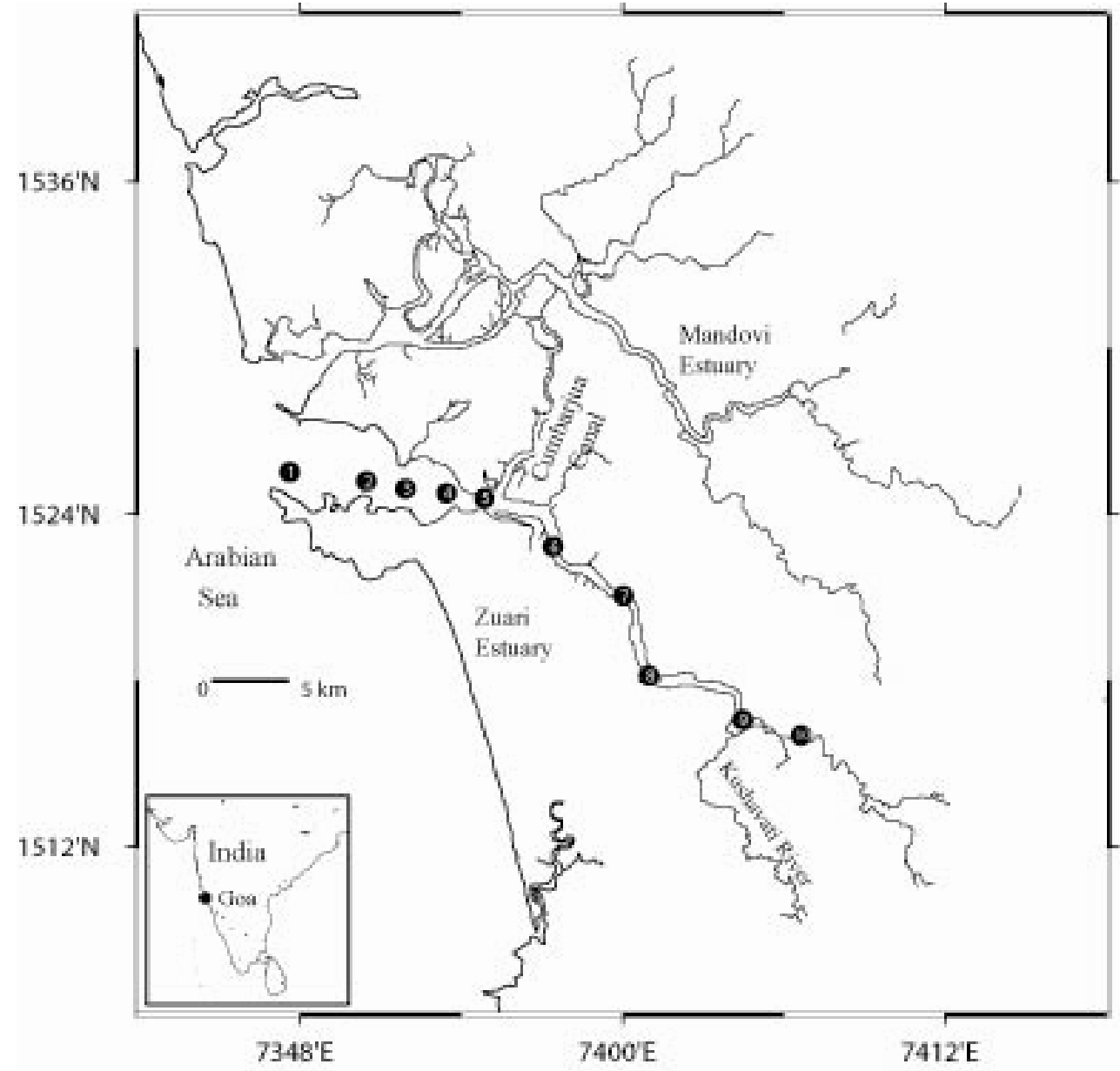

Fig. 1 

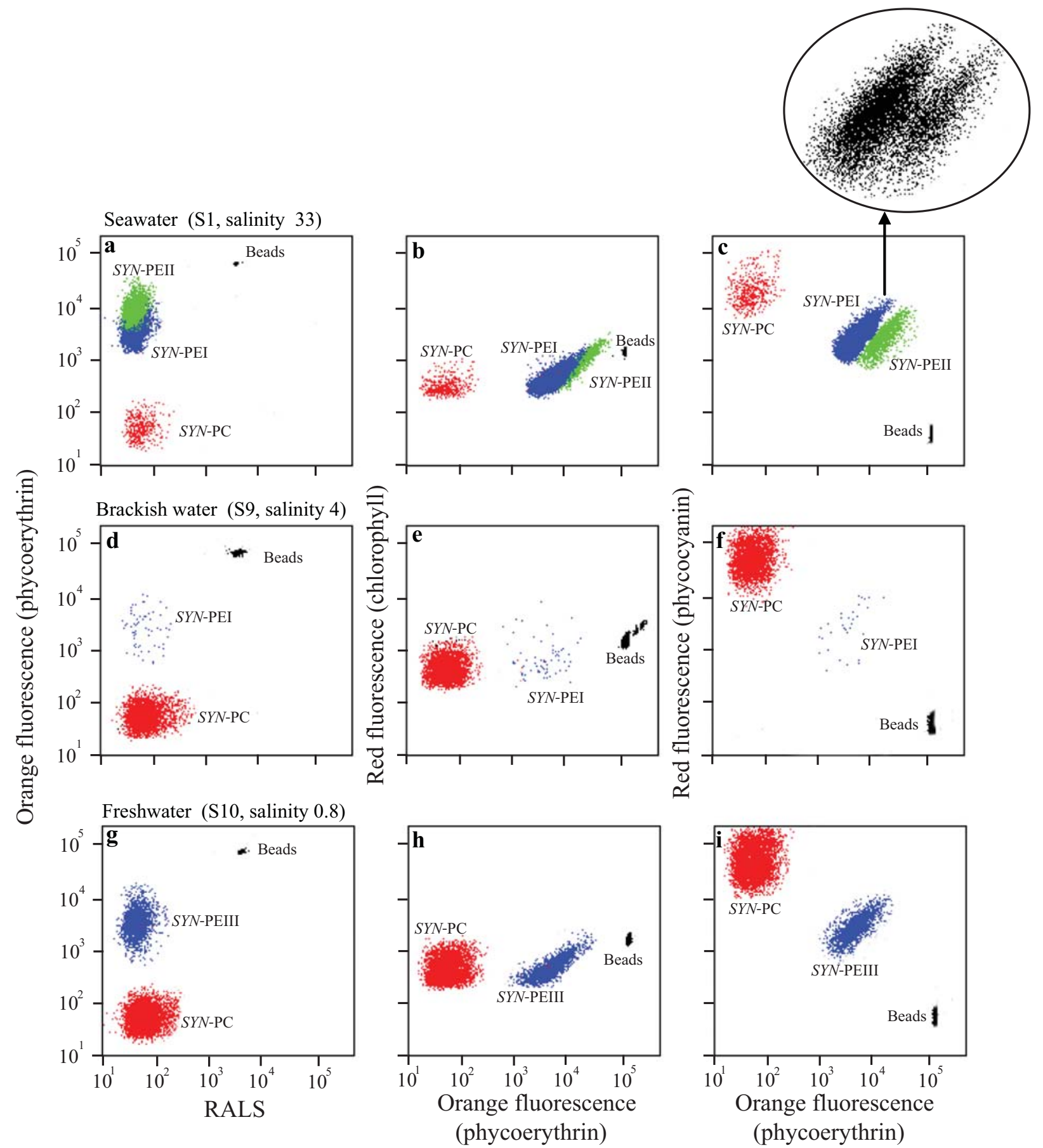

Fig. 2 

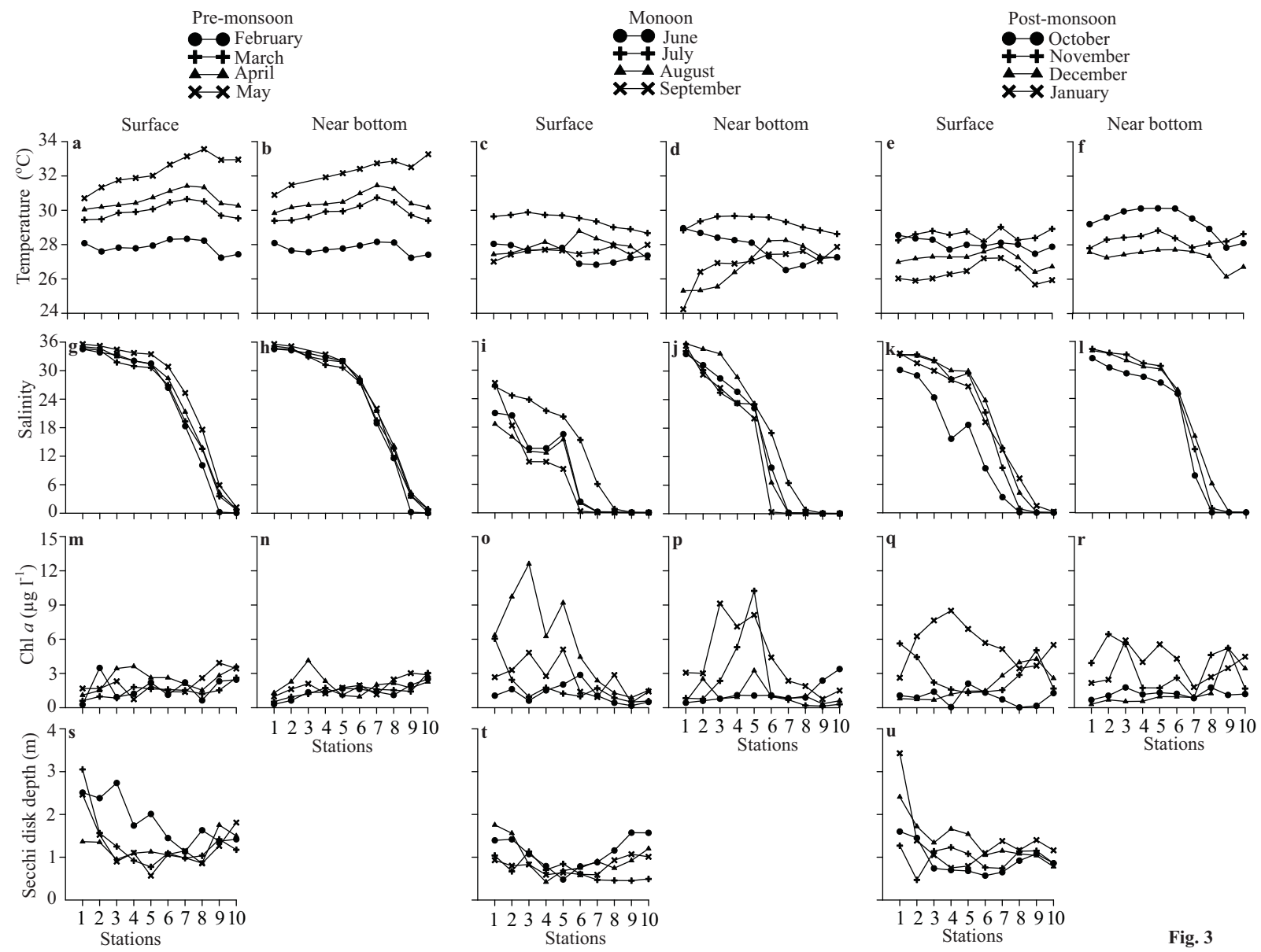

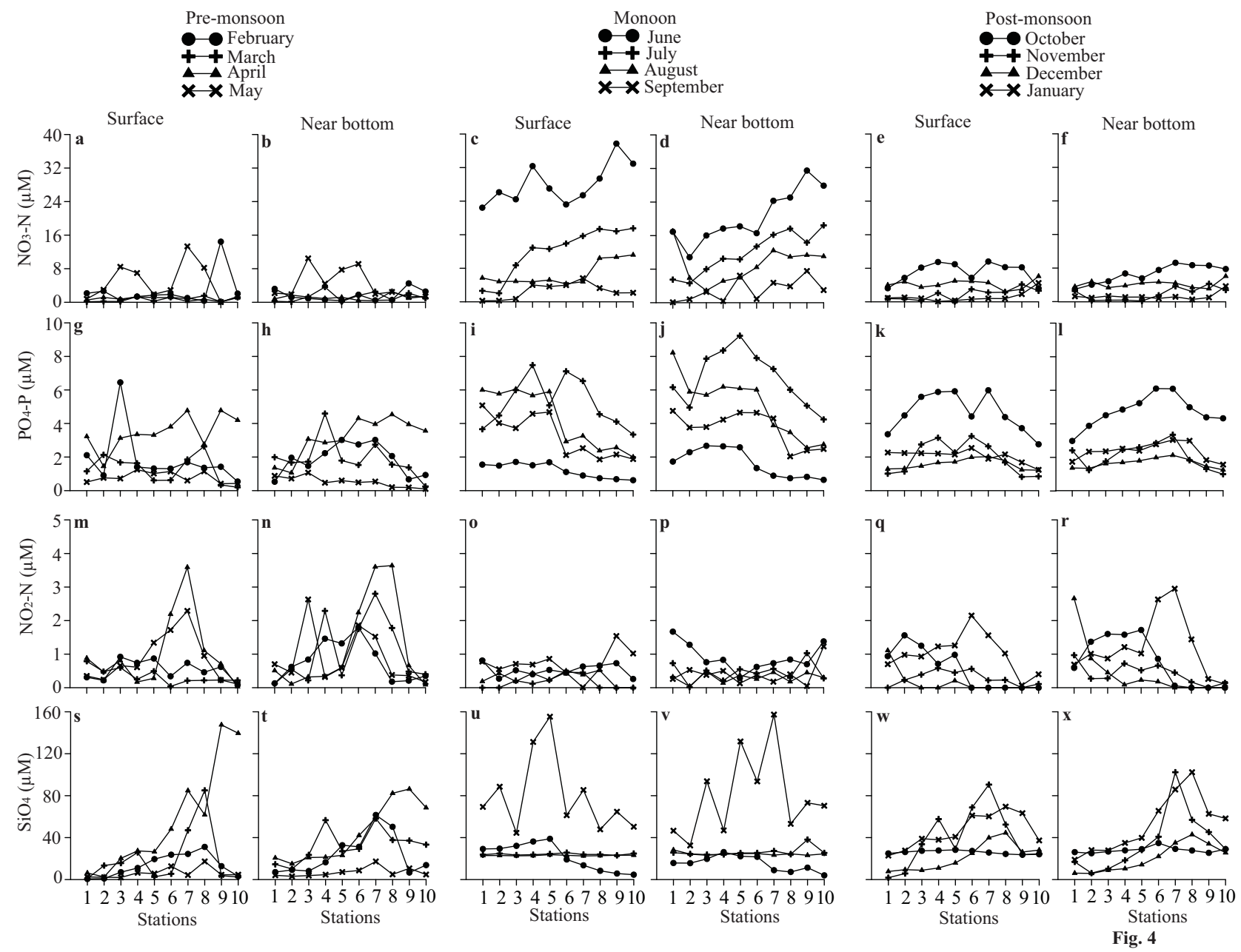


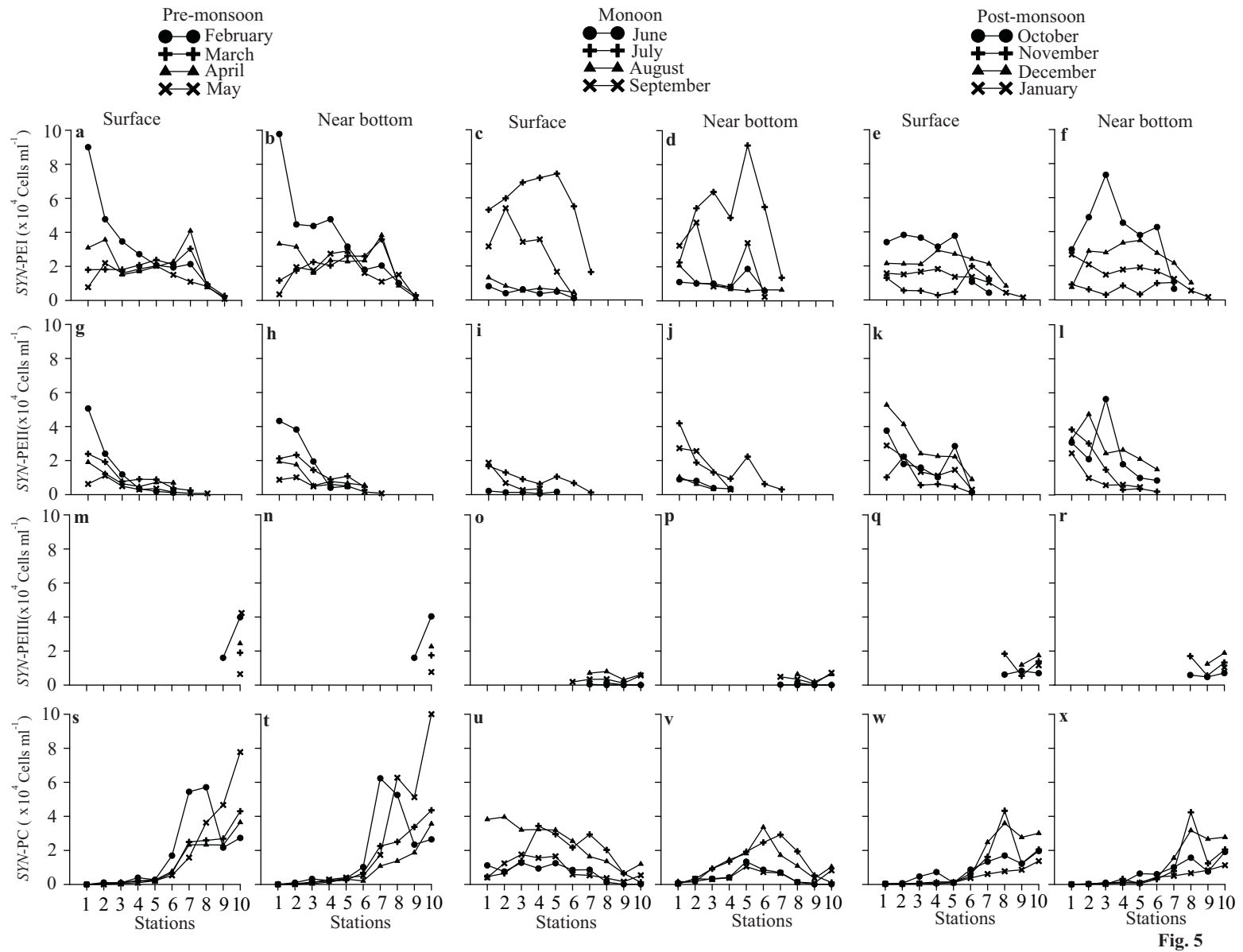



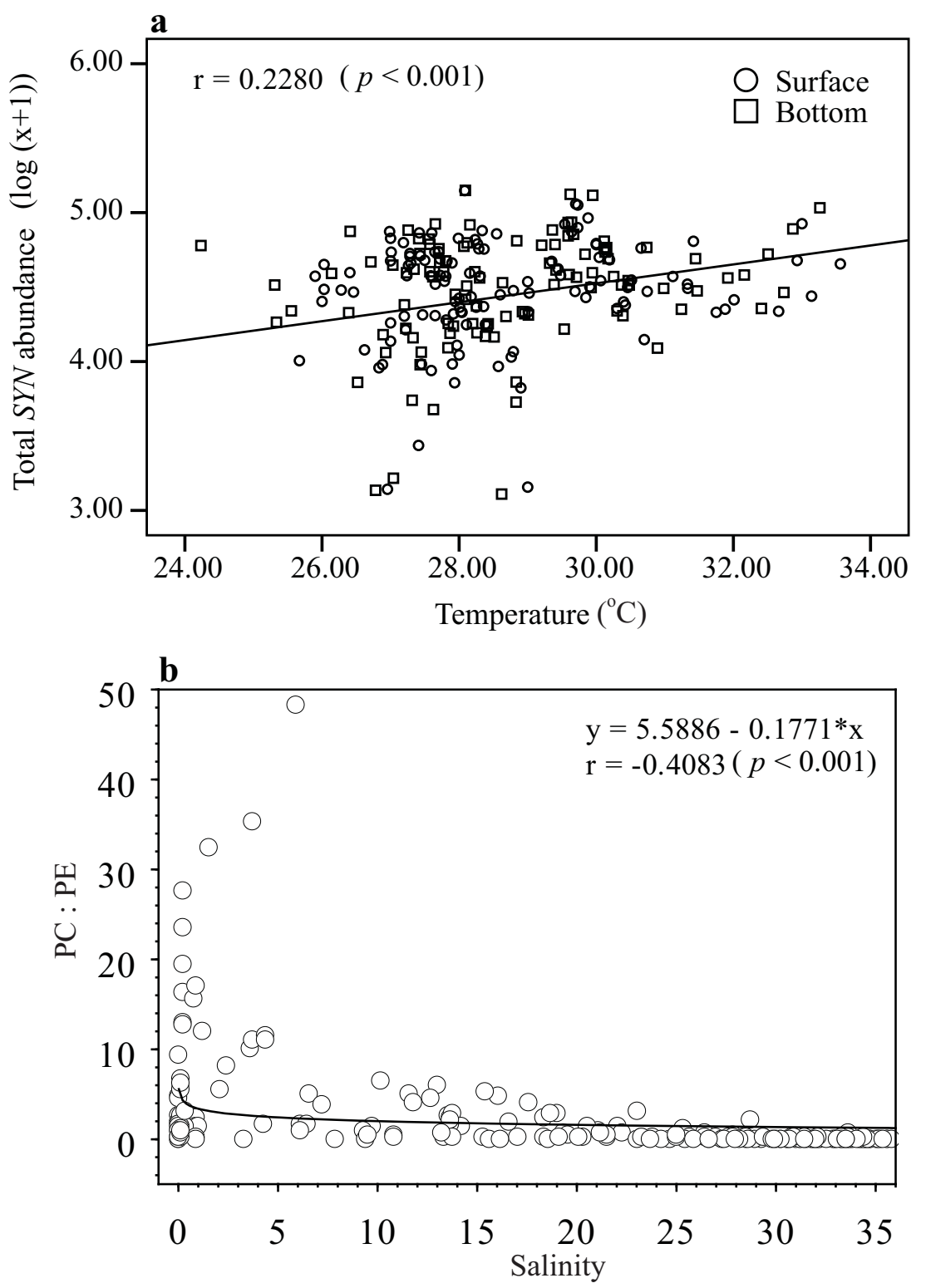

Fig. 6 

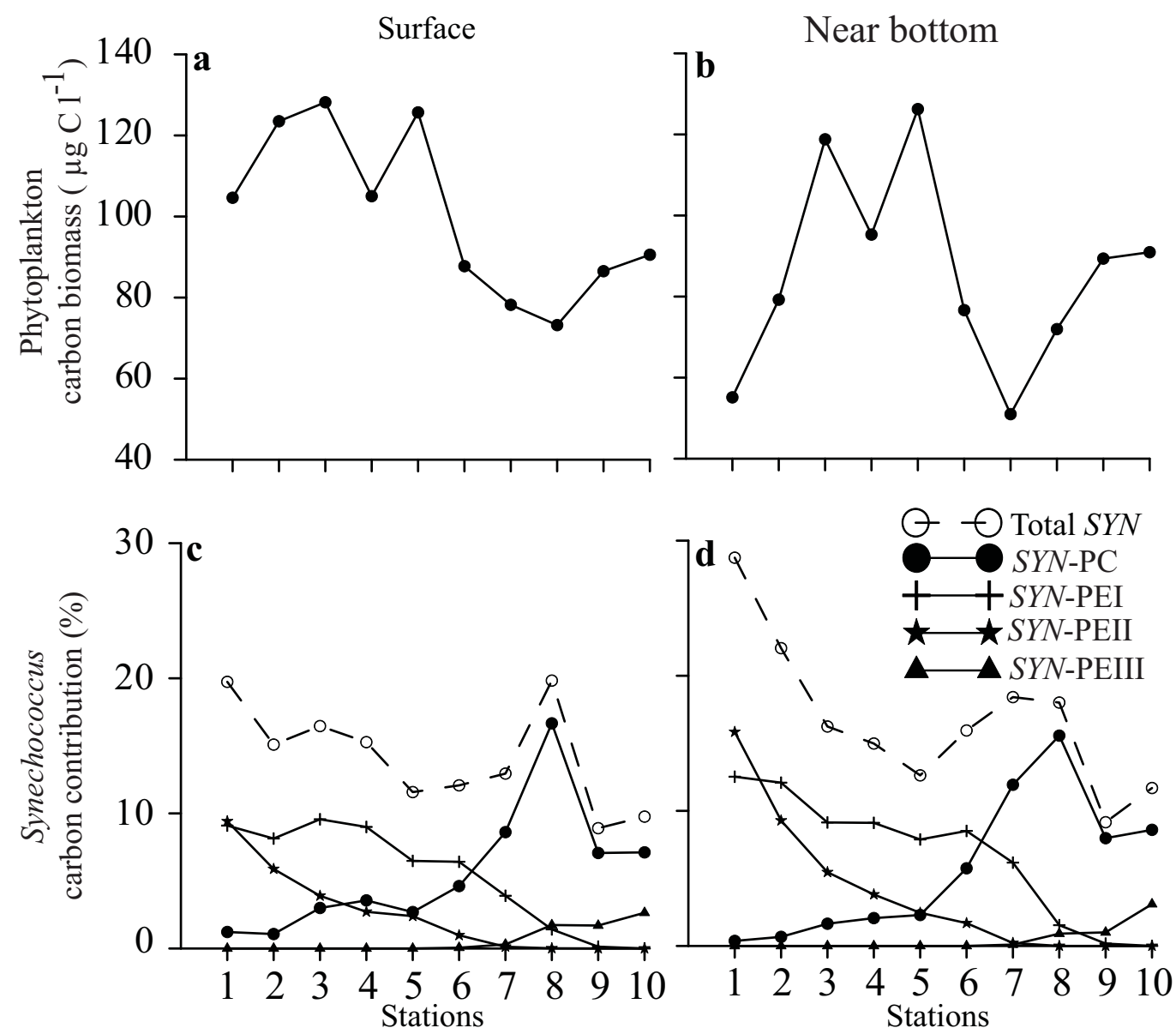

Fig. 7 

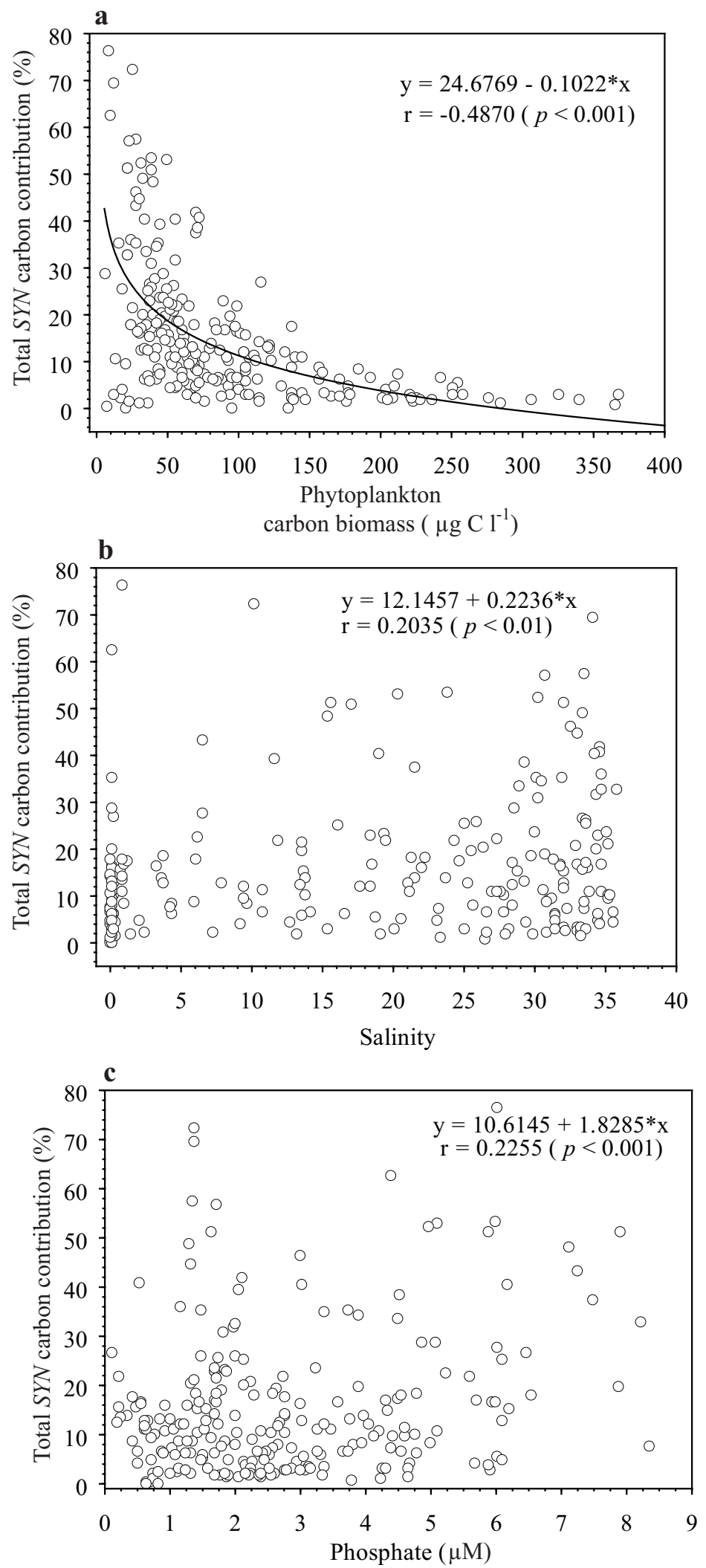

Fig. 8 